\title{
Margaret McCartney: We must fight the gravitational pull between money and power
}

\author{
Margaret McCartney general practitioner
}

Glasgow

Discourse about healthcare is broadly dominated by politicians, unions, medical royal colleges, and think tanks.

Think tanks often have highly visible publication streams calling for change, assessing or proposing policy, or scrutinising data, and their reports can drive the news agenda for days. Many of these reports have the academic rigour or carry the credentials of a scholarly essay_but some do not.

The think tanks are a curious assemblage. They have the freedom to publish research or views that a university may not fund-certainly, universities shouldn't be the only source of intellectual challenge to policy making.

But is the level of influence from think tanks appropriate? Many emphasise their claims to independence, and several are set up as charities. Invitation-only dinners and "events" may be used as private meetings to influence politicians. ${ }^{1}$ Some of the think tanks are paid for from wealthy endowment funds, raising additional money by running courses and conferences. The Institute of Economic Affairs-which has criticised plain cigarette packaging, minimum alcohol pricing, and the NHS in general-has come in for particular criticism for a lack of transparency over funding. ${ }^{2}$ Think tanks do not tend to be membership organisations.

Health think tanks approved of more competition in the NHS. There's a lack of evidence that this has done anything other than waste money and lower morale

Free speech and open debate are essential. But so too is transparency: think tanks shouldn't be used as a conduit to lobbying when the same message delivered directly by their funders would not garner such serious media attention.

Such lobbying prompts two broader concerns. The first is about representation. Think tanks are successful at achieving visibility and influence. But do they do a good enough job of representing evidence or uncertainty, and do they seek out challenge to their views? Consider that mainstream health think tanks approved of more competition in the NHS after the Health and Social Care Act 2012. There's a subsequent lack of evidence that this has done anything other than waste money and lower morale. The second concern is that think tanks are funded at all. All healthcare professionals face similar challenges: a combination of work and domestic commitments doesn't easily fit with the request to give up a day, far from home, to take part in the debates that think tanks organise to decide policy suggestions.

Who is included and who is excluded matters. This is why we pay representatives, for example, from the BMA or the medical royal colleges, to go to these meetings and ask difficult questions on our behalf. In his 2017 book On Tyranny, ${ }^{3}$ Timothy Snyder writes, "It is institutions that help us to preserve decency . . . Choose an institution you care about-a court, a newspaper, a law, a labor union—and take its side."

Holding power to account is hard work. Influencing policy is often painstakingly time consuming. But doctors need to be involved, even in a small way, in and by organisations that will have us as members and whose side we can say we're on, and vice versa. Because, if we don't, the usual gravitational field of money will continue to attract power, with little left to question it.

Competing interests: See www.bmj.com/about-bmj/freelance-contributors/margaretmccartney

Provenance and peer review: Commissioned; not externally peer reviewed.

1 Shaw SE, Russell J, Greenhalgh T, Korica M. Thinking about think tanks in health care: a call for a new research agenda. Sociol Health IIIn 2014;36:447-61.

10.1111/1467-9566.12071 24111597

2 Who Funds You? The UK campaign for think tank transparency. http://whofundsyou.org/ about.

3 Snyder T. On tyranny. Bodley Head, 2017.

Published by the BMJ Publishing Group Limited. For permission to use (where not already granted under a licence) please go to http://group.bmj.com/group/rights-licensing/ permissions 